The patents granted to R. Gans and the J. D. Riedel A.-G. in I909 (French Patent 405,990, July I 7 , I909; 'English Patent 2I,184, Sept. I6, I909; and U. S. Patent $95 \mathrm{I}, 64 \mathrm{I}$, March 8, I9 Io) contain claims for a process for remoring iron and micro-organisms from water. It is stated that the process consists in treating the water with insoluble higher oxides of manganese with the coöperation of natural or artificial zeolites (cf. German

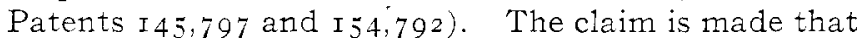
if a calcium-zeolite is treated with a solution of a manganous salt, a manganese zeolite is formed, which, on treatment with a solution of calcium permanganate, yields a product consisting of the higher oxides of manganese distributed in a fine state of division throughout a calcium-zeolite. According to Gans (Chem. Ind., 32, I 97$) .450 \mathrm{~kg}$. of calcium-zeolite were found to be changed, by washing with manganous chloride solution, to manganese-zeolite; treatment with a calcium manganate solution converted the latter into calcium-zeolite again. On filtering the water to be treated through this material. the iron is said to be rapidy oxidized and removed, and the bacteria and organic matter destroyed; any manganese present in the water is also said to be removed. In later patents to the same parties (French Patent 409,006, Nov. I 3, I909; English Patent 26,842, Nov. I8, I909; and C. S. Patent 960,887, June 7 , I910), the water to be softened is treated with barium, calcium or magnesium hydroxide, and sodium hydroxide or carbonate, according to the nature of the hardness, and then filtered through a layer of a natural or artificial zeolite.

When a water containing manganese salts in solution is passed through a filtering bed composed of a zeolite impregnated with higher oxides of manganese the manganese is separated in the form of a mud. It was found in practice as early as 1907 that if this mud was not removed from the filter, it eventually formed small porous particles which did not interfere with the filtering capacity of the bed, but, in fact, increased its efficacy with regard to the removal of manganese from water (see German Patent 220,609, Oct. 28, Igo8, of the ]. D. Riedel A.G). However, when revivification was attempted- $i, e$, on the bed containing manganese mud-the manganese retained was found to be an obstruction to rapid filtration.

Natural stones, such as trass, phonolite, porphyry, leucite, trachyte, sodalite, and mica, are also employed in making filters through which the water to be treated is passed. These minerals are used either directly, if they have been hydrated naturally, or after they have been treated with steam under pressure; but we are not aware of their application in the place of artificial zeolite.

Two investigations have recently been published on "Permutite." Anders (Toch. f. Brau., 28, 78) conducted laboratory experiments with the product for the softening of water. His results showed that "Permutite" is applicable for the softening of feed-waters, but not for mash-waters because it takes up sodium salts. He found that a "Permutite" filter may be completely regenerated by the use of a sodium chloride solution.
Kolb (Chem. Ztg. 35, I 393, r 4 ro) also investigated the application of "Permutite" to the softening, as well as the purification, of water. He made experiments, both by shaking and by filtration, as to the interchange occurring between "Permutite" and the chlorides of calcium, magnesium, and potassium, and found that the soda of the "Permutite" was replaced by the bases of the salts added in molecular proportions. He also ascertained that the "Permutite" could be regenerated by treating the used substance with sodium chloride, and that iron and manganese, as well as the alkaline earth metals, could be removed from solution. Kolb stated that with a filter formed of "Permutite," complete softening of water could be effected, but the water must not contain acid or suspended matter. In the case of a muddy water, in addition to blocking the pores of the filter, the mud coated the grains of the filtering material with inert matter and prevented the desired chemical reactions. Kolb considered the regeneration of the "Permutite" by a solution of sodium chloride to be of industrial importance, since it would enable the same filter to be used for an indefinite period. According to his findings, the richness of the treated water in sodium salts is not detrimental to boiler-fecd water.

It would seem that "Permutite," to be of value for technical uses, must be of a granular or leafy, easily porous character, such as is obtained by melting together the constituents in definite proportions. The amount of clay is calculated according to the amount of bases. Gans considers that the composition of an ideal zeolite, ${ }_{2} \mathrm{SiO}_{2} \cdot \mathrm{Al}_{2} \mathrm{O}_{3} \cdot \mathrm{Na}_{2} \mathrm{O} \cdot 6 \mathrm{H}_{2} \mathrm{O}$, should be approached.

W. A. HAMOR.

\section{THE PAINT AND VARNISH INDUSTRY OF THE UNITED STATES.}

Up to ten years ago this industry was more or less in an empirical state. Even the manufacture of dry colors, such as chrome yellow, Prussian blue, chrome green, etc., which are purely chemical colors-and the reaction can be figured out molecularly-was carried on by men who had what they thought were secret formulas, and if more of one liquid than another was added, no note was taken of it. The mixed paint industry was also in a somewhat chaotic state, but a few men came to the realization that white lead was not the only pigment, and linseed oil and turpentine not the only vehicles which could be used. The mixed paint consumption to-day amounts to eighty million gallons per year, and such materials as barytes, blanc fixe, lithophone, sublimed white lead silica, etc., are now regarded as beneficial accessories, rather than adulterants.

With the co-operation of the Department of Agriculture, such rehicles as soya bean and china wood oils are receiving marked attention. China wood oil is to-day such a necessity that the revolution in China, which has brought the price of the oil up to 
\$.IO per gallon, has made it apparent that the paint and varnish manufacturer must have it at any price.

The shortage in the crop of flaxseed has not produced that tremendous market disturbance which was feared two years ago, for many prominent chemists have published methods for the use of Menhaden fish oil. which in many respects has shown itself to be at least as good as linseed oil.

The same condition has prevailed in the turpentine market, for in March, IgII, when the price reached $\$$ I.I3 per gallon, the United States Navy decided that for its work a good turpentine substitute made from petroleum would answer its requirements, and the government is now using thousands of gallons of turpentine substitute for which it pays from twelve to fifteen cents per gallon. As the Navy purchased in Igro about $\$ 70,000.00$ worth of turpentine, this innovation has had a tremendous effect on the turpentine market, and the chances are it will never see such an abnormally high price again.

There seems to be a difference of opinion, all over the United States, regarding the materials to be used for paint, for it is conceded that paint should be made for the purpose for which it is intended, and should not necessarily be made of the highest priced materials which will produce that result. The Battleship Gray which the Government has partially adopted for the navy is made of 45 per cent. zinc oxide and 45 per cent. barium sulphate, with the necessary tinting material to produce the shade. A paint made of such materials costs about 25 per cent. less than the lead and zinc paints which were formerly used. The results showed that the zinc oxide and barium sulphate paint dried with a harder film and was not affected by salt water as much as the lead paint formerly used.

A similar condition of affairs has developed in the maintenance departments of the large railroads of the United States, and they have come to realize that no single pigment is as good as a mixture of pigments, and no single pigment is as good as a pigment which contains a reinforcing material in limited amounts.

The trend of opinion among paint manufacturers seems to be that they are more inclined to talk freely than they have been heretofore. Twenty-five years ago a paint manufacturer regarded a formula which he had as a valuable secret, but chemists who have made a specialty of the analyses of paints and their syntheses have shown that the average pigment mixed with oil, dryer and a volatile thinner is not a difficult mixture to analyze, and many of the secrets of the ignorant paint manufacturers have been exposed for their own benefit. Instead of having what they thought were valuable secrets, they had in many instances only mediocre formulas, which they improved when they saw what their competitors were doing.

Paint is so largely an engineering material that a knowledge of its composition is not to be treated lightly, and must not be regarded as an extravagance. Paint for decorative purposes presents new problems. The question of hygiene has entered so much into the use of paint that the wall paper manufacturers in England are now going into the manufacture of interior wall paints because people want washable walls in preference to those which harbor filth and germs.

Maximilian Toch.

\section{ORIGINAL PAPERS}

\section{CARBON BRUSHES.}

BY W. R. WHITNEY.

Received January 24, 1912.

The object of this paper is to describe some experiments which are being carried out with the view of assisting in an improvement in the qualities of motor and generator brushes, particularly of the carbon type. It is well known that while there have been very many improvements in all sorts of electrical apparatus during the past twenty years, there has not been a corresponding improvement in the quality of brushes, at least in this country. It is a peculiar commercial or manufacturing condition which all engineers will recognize when their attention is called to it-that an electrical manufacturing company usually puts upon its motors and generators all the legitimate accessories of its own make which are possible, excepting the brushes, and forces the users to purchase brushes from companies not necessarily in very close touch with electrical requirements.

If the brush was as simple an article of manufacture as the lag screw with which the apparatus is attached to the floor, this would not be serious, but quite a different condition exists. In fact, I think it is safe to say that a poor carbon brush, or brush of a wrong type, may render inoperative any kind of electrical apparatus. When one considers the stoppage of a long line of electric cars or the temporary shut-down of a generating plant, because of defects in a brush, one wonders that the demands have not already made an art of brush-making. One finds, in fact, that the production of this very essential, unobtrusive little block of carbon has had hardly any study at all.

Every electrical machine is carefully designed in detail as to size and shape of copper, iron and insulation, all of which vary with each machine, but as yet the important characteristics of a brush are not included in the design, although some one grade of brush is expected to operate satisfactorily over a great range of design. As long as this unfortunate condition exists, the best that can be hoped for is a brush which will do fairly well for a large number of machines, very well on a few and cause continuous trouble on a small balance until investigation of the constants of the particular machine, or its operating condition, shows the need of a different type of brush.

The careful investigation now in progress leads us to hope that the various characteristics of carbon 